\title{
Esophagoenteral stents in patients with recurrent gastric adenocarcinoma
}

\author{
F. Pérez-Roldán, P. González-Carro, M. Legaz-Huidobro, M. Oruezabal-Moreno', S. Soto Fernández, \\ O. Roncero García-Escribano, A. de Pedro Esteban, F. Ruiz-Carrillo and J. Seoane-González ${ }^{2}$
}

Units of Gastroenterology, ${ }^{1}$ Oncology and ${ }^{2}$ General Surgery. Complejo Hospitalario La Mancha-Centro. Alcázar de San Juan. Ciudad Real, Spain

\begin{abstract}
One of the problems that can appear in patients with total gastrectomy for adenocarcinoma with esophagoenteral anastomosis is the appearance of a stenosis of the anastomosis. These stenosis are frequently malignant due to relapse of neoplasia. The therapeutic possibilities available are the surgical bypass or palliative treatment. There is very little experience described in the literature (21 cases) on the placing of self-expandable metal stents as a palliative treatment for the symptoms of stenosis.

We present our experience of 3 patients, in whom 4 esophageal stents were fitted (1 covered and 3 uncovered) with good results. The dysphagia disappeared or improved, it allowed the ingestion of a soft diet and meant an improvement in the quality of life and at the same time stopped the weight loss. It seems an effective palliative treatment as a treatment for dysphagia in patients with tumoral relapse in the anastomosis of total gastrectomies.
\end{abstract}

Key words: Stents. Total gastrectomy. Relapse. Carcinoma.

Pérez Roldán F, González Carro P, Legaz Huidobro M, Oruezabal Moreno M, Soto Fernández S, Roncero García-Escribano $O$, de Pedro Esteban A, Ruiz Carrillo F, Seoane González J. Esophagoenteral stents in patients with recurrent gastric adenocarcinoma. Rev Esp Enferm Dig 2006; 98: 341-349.

\section{INTRODUCTION}

In recent years there has been a progressive increase in gastric adenocarcinoma, together with improvements in

Recibido: 01-02-05

Aceptado: 11-05-05.

Correspondencia: Francisco Pérez-Roldán. Unidad de Gastroenterología. Complejo Hospitalario La Mancha-Centro. Avda. de la Constitución, 3. 13600 Alcázar de San Juan (Ciudad Real). Fax: 926547700. its surgical and oncologic treatment. Increasingly more rescue surgeries are being performed when localized relapses develop, while chemotherapy treatments are also administered with both curative and palliative purposes.

The existence of multi-disciplinary teams has enabled a more extensive management of these neoplasms, and has particularly pointed what to do when inoperable relapses appear with significant clinical manifestations such as vomiting, dysphagia, and weight loss. There is little published experience on the treatment to follow when we find ourselves facing a malignant stenosis in patients with an esophagojejunal anastomosis after a total oncological gastrectomy. Therapeutic possibilities include surgical bypass and palliative treatment. Within possible palliations is the insertion of an esophagoenteral stent, but there is little experience thereof in the literature (1-9).

The objective of this work is to describe the palliative efficacy of esophagoenteral stents in patients after total gastrectomy, and with a subsequent relapse of their gastric neoplasm at the anastomosis or next to it.

\section{PATIENTS AND METHODS}

During the period between 1999 and January 2003, 130 stomach neoplasms were diagnosed out of 5,432 upper GI endoscopies undertaken (2.39\%). Of these, 3 patients were subjected to total gastrectomy with curative intent, and subsequently suffered a tumor relapse at the anastomosis site. All three patients had the same symptoms, including the presence of dysphagia and vomiting with weight loss. Treatment consisted of the placement of esophagoentereral stents using endoscopy -with an Ultraflex ${ }^{\circledR}$, covered or otherwise, from Boston Scientific Corporation S.A.- in order to palliate the symptoms of patients.

The prostheses were placed under endoscopic vision, leaving the end of the stent in the small intestine and the 
proximal side in the esophagus. Also, we had radiologic control in order to check the situation and opening of the stent. The patient remained at rest for 24 hours, and after a control X-rays to check the correct placement of the prosthesis, they were put on a liquid diet.

All 3 cases reported, and their clinical outcome are described below.

\section{Case 1}

A 41-year-old woman had undergone total gastrectomy with Roux-Y reconstruction after presenting with a poorly differentiated gastric adenocarcinoma 2 years earlier. Chemotherapy was associated according to cisplatin and iridotecan guidelines, and 12 cycles were given. She required rescue surgery at 18 months for a local extraluminal tumor relapse -terminolateral anastomosis with Roux-Y reconstruction and subtotal colostomy with terminolateral ileocolic anastomosis and associated ileostomy. Surgical pieces clearly showed an infiltration of the peritoneum, colon, and previously ascended intestinal loop, and in the esophageal reflux area from resection.

She was referred to the Gastroenterology Department for progressive dysphagia two months after surgery, accompanied by weight loss. An esophagogram was performed in which a distal esophageal stenosis was found, and subsequently an upper digestive endoscopy was done: distal esophageal stenosis with normal mucosa, with biopsies being negative for malignity; she also had sutures and surgical staples. It was decided to remove the sutures, and she was given 6 sessions of pneumatic dilation, but these were ineffective. Given the suspicion of transmural neoplastic infiltration and the continuing dysphagia, an uncovered esophageal stent of $7 \mathrm{~cm}$ was fitted (Fig. 1). On expanding the stent, neoplastic infiltration could be seen. After 48 hours she could take a soft diet and showed a clearly improved dysphagia. The patient also received cycles of associated palliative chemotherapy.

Eight months after stenting there was a recurrence of dysphagia and weight loss. At endoscopy a neoplastic growth could be seen through the stent (Fig. 1); it was decided to insert a covered esophageal stent $10 \mathrm{~cm}$ in length. The patient was restarted on oral feeding, and her dysphagia improved. She died 6 months later from systemic tumor invasion.

\section{Case 2}

A 58-year-old woman had undergone total gastrectomy with Roux-Y reconstruction for a Lauren's diffuse, poorly differentiated gastric adenocarcinoma 1 year before. She needed a second surgery a month later to address an infiltration of the esophageal anastomosis ring, and also chemotherapy was added. A year later an upper endoscopy was per- formed to study progressive dysphagia with weight loss, which showed evidence of tumor relapse with associated esophageal stenosis. It was decided to insert an uncovered 7$\mathrm{cm}$ stent - dysphagia disappeared and ingestion became possible. Biopsies taken from the stenosis were positive for malignity. The patient received palliative chemotherapy.

She died 8 months after stenting from tumor progression, peritoneal carcinomatosis, and pulmonary metastases without dysphagia.

\section{Case 3}

A 69-year-old man had undergone total gastrectomy with Roux-Y reconstruction for a poorly differentiated gastric adenocarcinoma 12 months earlier. For backup treatment he was given radiotherapy and chemotherapy, after which he showed peritoneal implants in the histological study of the surgical piece. An upper endoscopy was performed for progressive dysphagia and weight loss, which demonstrated a fibrous ring at the esophagoenteral anastomosis, and a jejunal stenosis close to the anastomosis. Biopsies were taken, which were negative for malignity. Against the suspicion of local relapse from

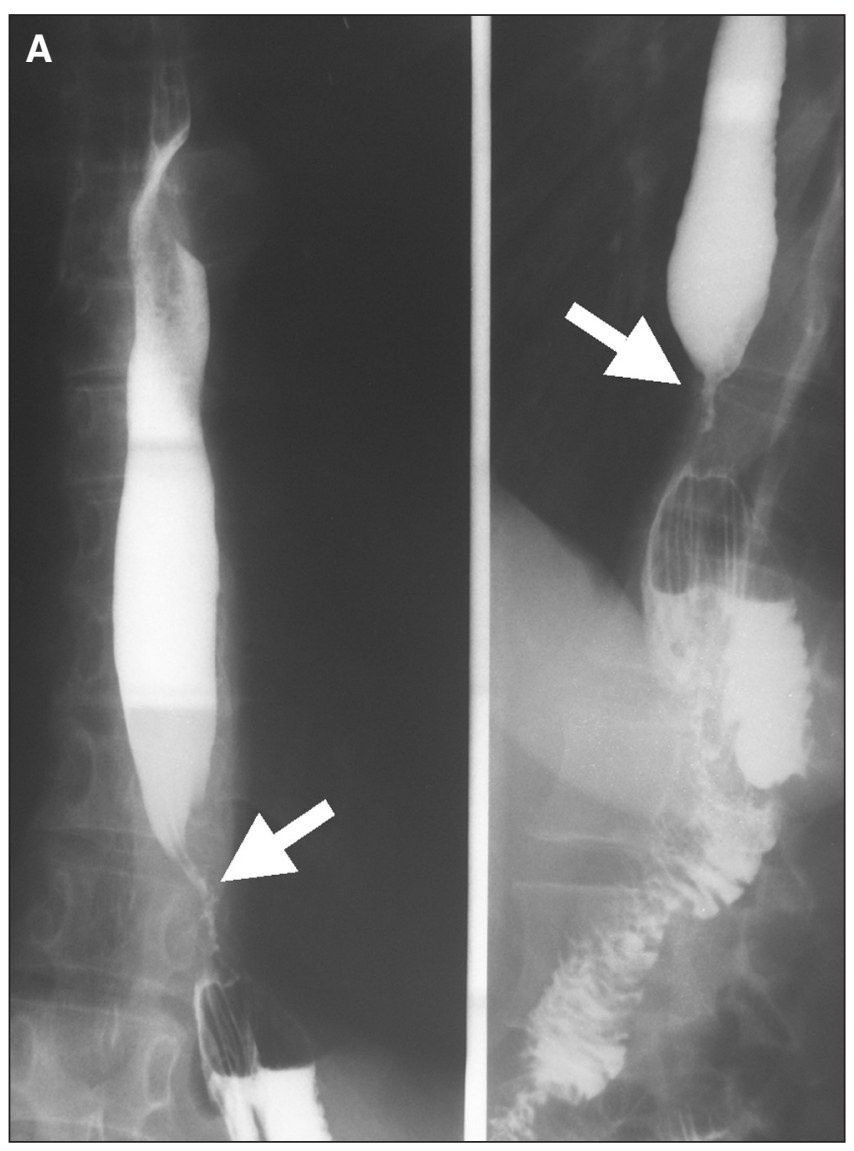

Fig. 1.- A. Esophagoenteral stenosis seen with barium radiology (arrows).

A. Estenosis esofagoenteral vista por radiología baritada (flechas). 


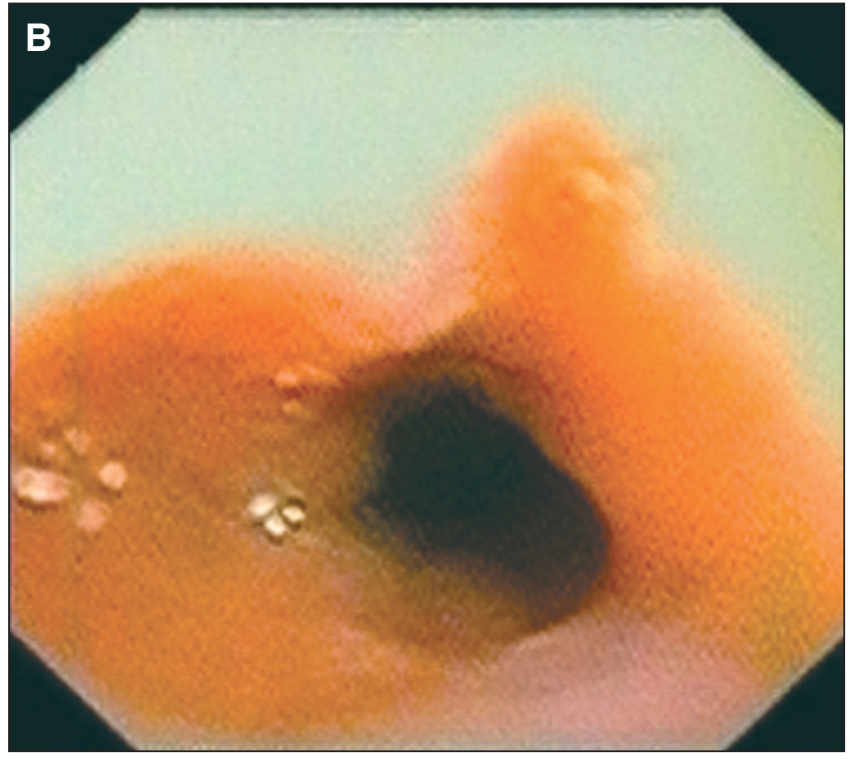

Fig. 1.- B. Endoscopic image of a stenotic site at the anastomosis. B. Imagen endoscópica de la estenosis de la anastomosis.

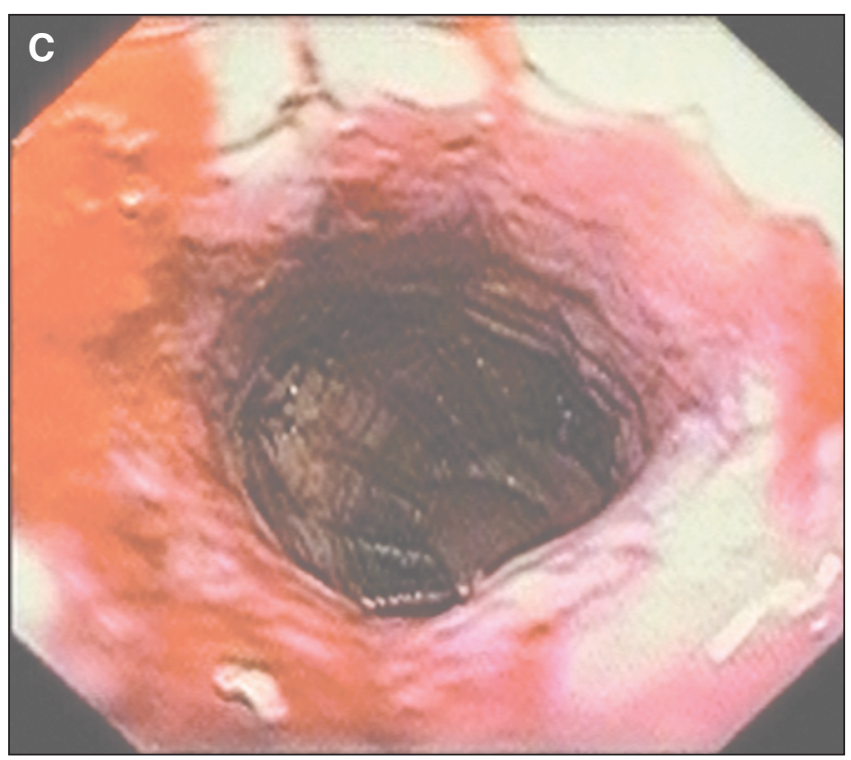

Fig. 1.- C. Uncovered expandable stent in place.

C. Prótesis expandible no recubierta colocada.

peritoneal carcinomatosis, an expandable uncovered 10$\mathrm{cm}$ esophageal stent was inserted (Fig. 2). The patient died 4 months later from systemic tumor invasion.

\section{DISCUSSION}

Metal stents have conventionally been used for the palliation of esophageal (10) and biliary neoplasms. Recently they have been given new uses, such as the palliation of obstructive colon neoplasms, treatment of obstructed gastric outlet, and duodenal compression $(3,11)$.

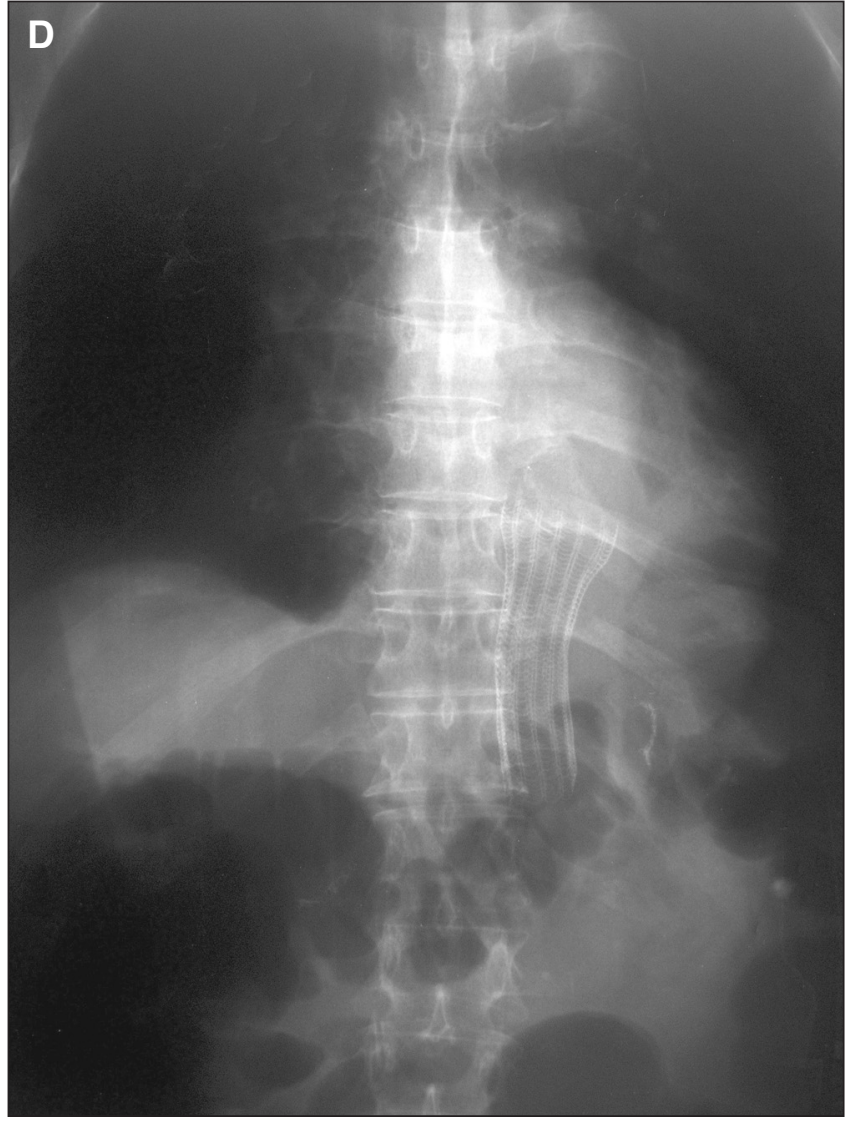

Fig. 1.- D. Plain radiograph showing an expanded stent in place. D. Radiología simple con prótesis colocada y expandida.

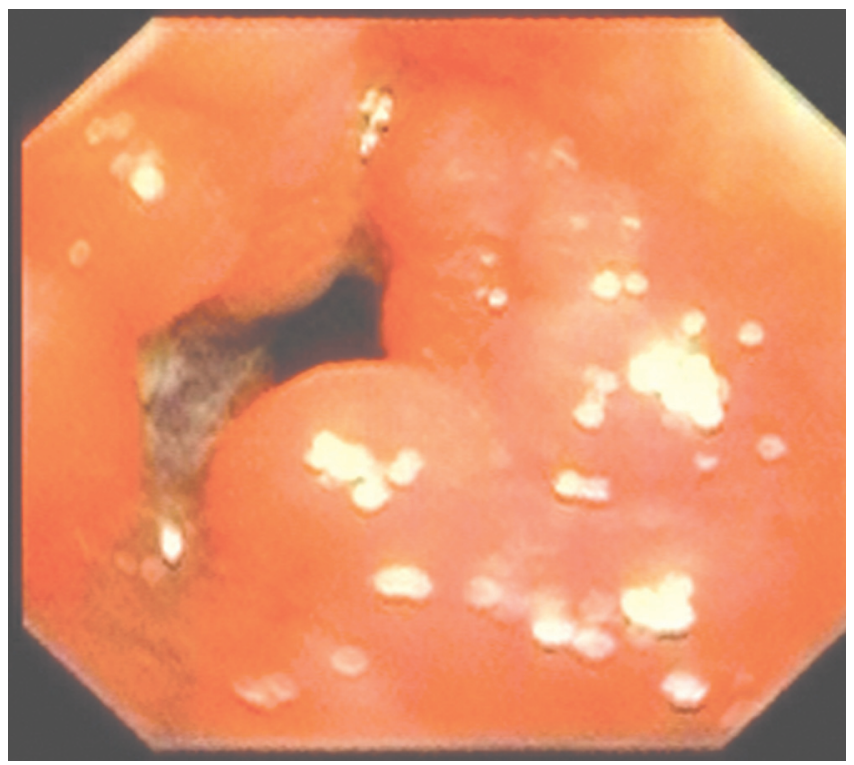

Fig. 1.- E. Tumor relapse developing over the expandable stent. E. Recidiva tumoral que reaparece sobre la prótesis expandible.

On the other hand, we should remember that, in spite of the improvement of surgical and oncologic therapies for gastric adenocarcinoma, problems have arisen, in- 


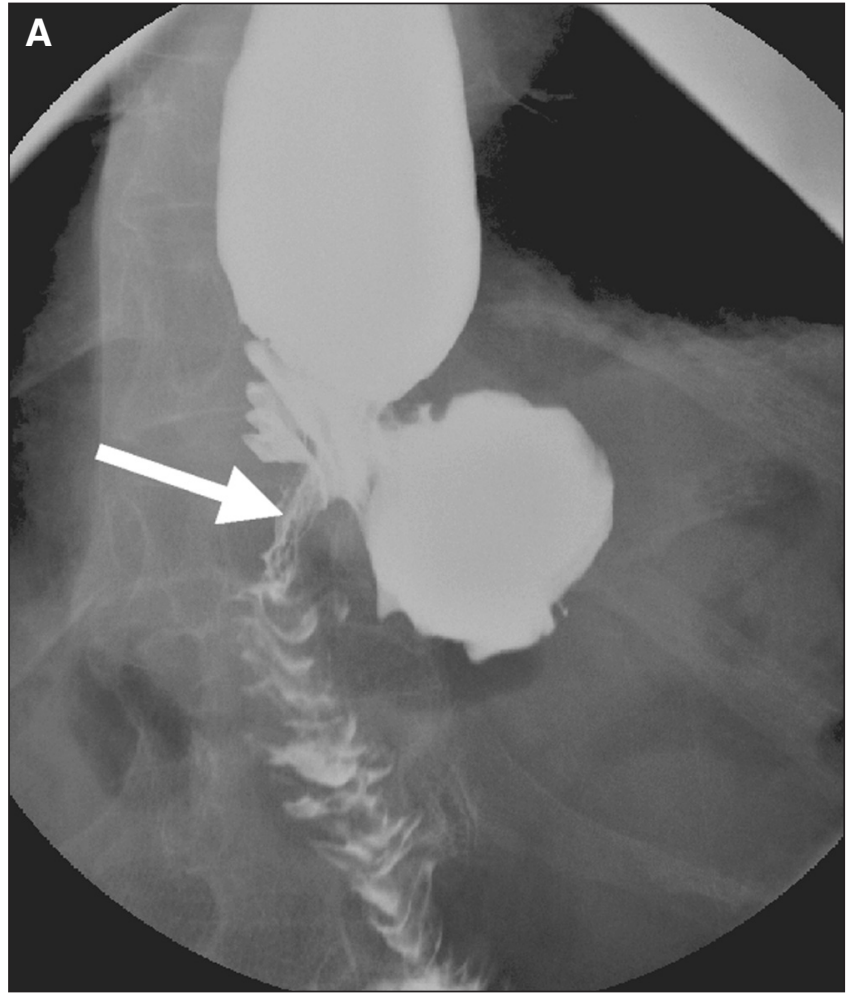

Fig. 2.- A. Stenosis in the intestinal loop close to the anastomosis in the radiological study (arrow).

A. Estenosis en asa intestinal próxima a la anastomosis en el estudio radiológico (flecha).

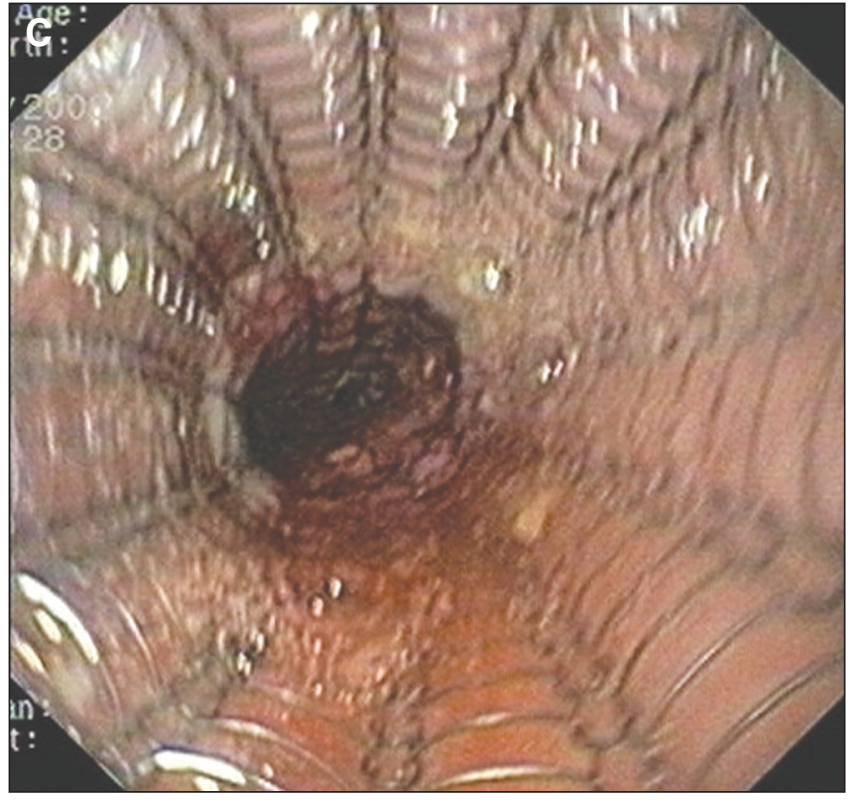

Fig. 2.- C. Uncovered expandable esophagoenteral stent in place. C. Prótesis expandible esofagoenteral no recubierta colocada.

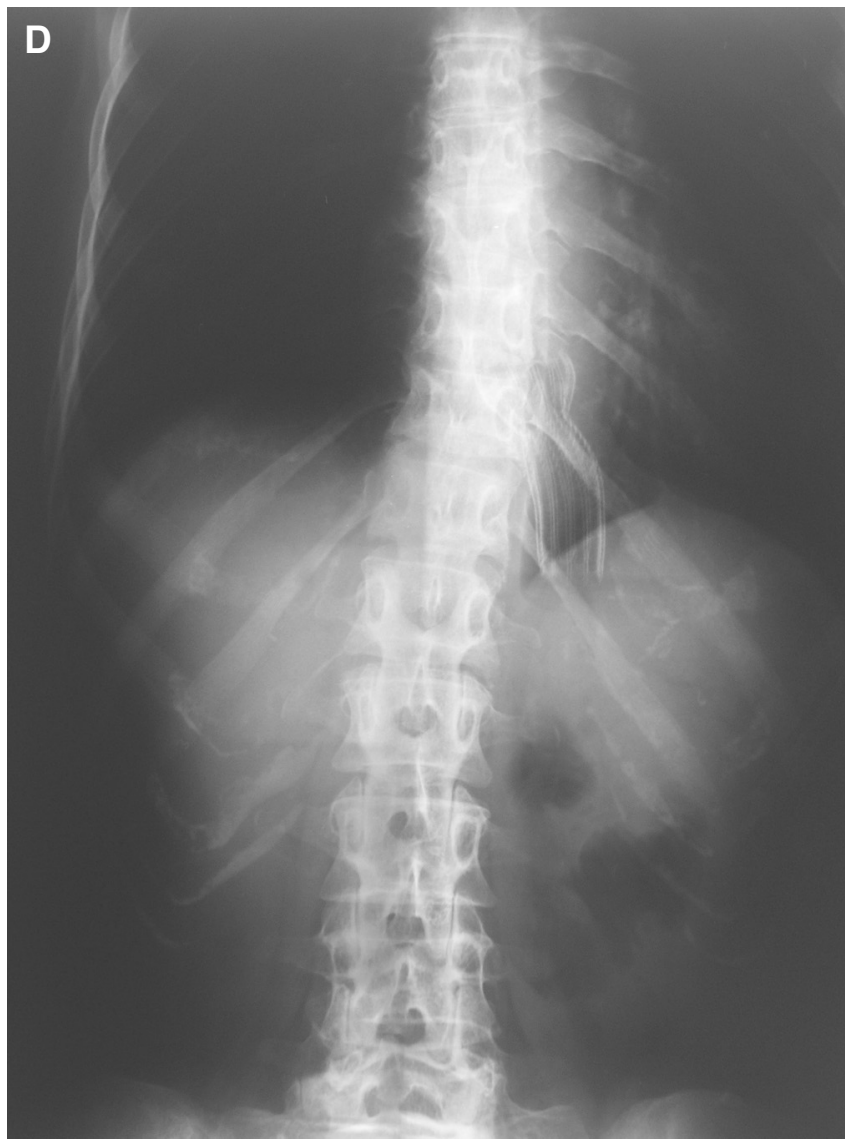

Fig. 2.- D. Abdomen radiograph with a stent placed and expanded. D. Radiología de abdomen con prótesis colocada y expandida.
Fig. 2.- B. Placing of the esophageal stent: a $0.035^{\prime \prime}$ guide in the intestinal loop.

B. Colocación de prótesis esofágica: guía de $0.035^{\prime \prime}$ en el asa intestinal.

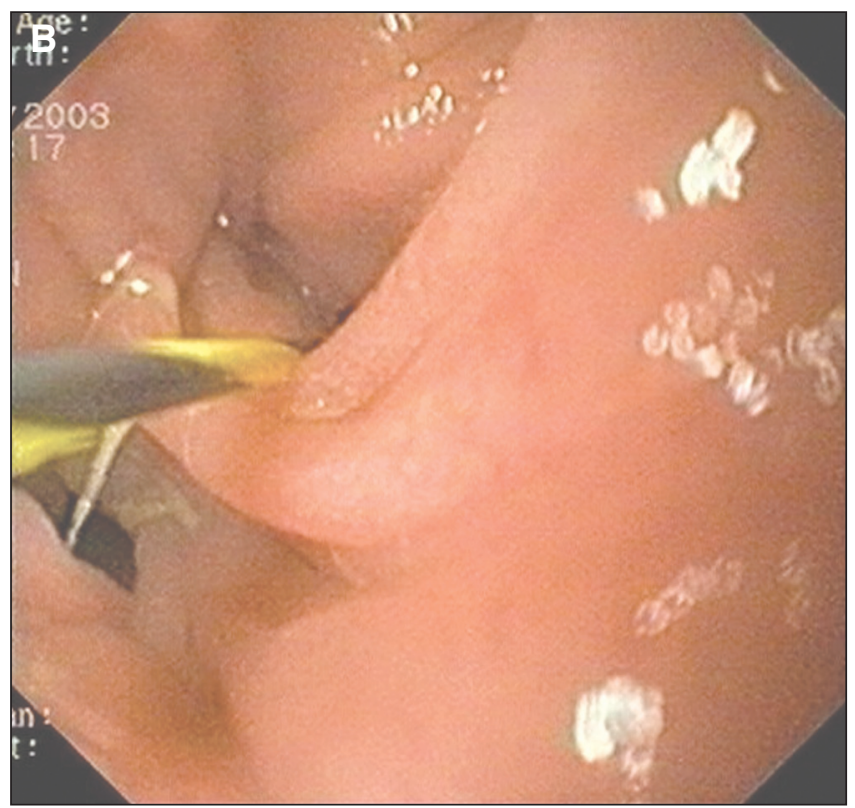


Table I. Published experience on expandable stents in patients with total gastrectomy for gastric neoplasia

\begin{tabular}{|c|c|c|c|c|c|c|c|c|}
\hline Author & Sex & Age & Localization & Cause & Stent $\left(n^{\circ}\right)$ & Survival & Placing & Cause of death \\
\hline \multirow{4}{*}{$\begin{array}{l}\text { Roy-Choudhury (1) } \\
\text { (4 cases) }\end{array}$} & M & 69 & Antrum & Leak & Ultraflex (1) & 13 months & X-ray & TEP \\
\hline & M & 67 & Corporeal & Leak & $\begin{array}{c}\text { Telestep (3) } \\
\text { Gianturco-Z (1) }\end{array}$ & 45 months & X-ray & Sepsis and empyema \\
\hline & M & 67 & Antrum & Leak & Ultraflex (1) & +7 months & X-ray & - \\
\hline & $M$ & 52 & Minor curv. & Leak & Ultraflex (1) & +7 months & X-ray & - \\
\hline $\begin{array}{l}\text { Ustundag (2) } \\
\text { ( } 1 \text { case) }\end{array}$ & M & 73 & $\begin{array}{l}\text { Corporeal- } \\
\text { fundus }\end{array}$ & $\begin{array}{l}\text { Benign } \\
\text { stenosis }\end{array}$ & Ultraflex (1) & - & Endoscopy & - \\
\hline $\begin{array}{l}\text { Sherwood (3) } \\
\text { (1 case) }\end{array}$ & $\mathrm{F}$ & 82 & - & $\begin{array}{l}\text { Malignant } \\
\text { stenosis }\end{array}$ & $\begin{array}{l}\text { Ultraflex (1) } \\
\text { Esophacoil (1) }\end{array}$ & 6 months & Endoscopy & Jaundice \\
\hline $\begin{array}{l}\text { Kozarek }(4) \\
\text { (1 case) }\end{array}$ & - & - & Not described & $\begin{array}{l}\text { Benign } \\
\text { stenosis }\end{array}$ & Not described & - & Endoscopy & Not described \\
\hline $\begin{array}{l}\text { Winkelbauer (5) } \\
\text { (4 cases) }\end{array}$ & $\begin{array}{l}- \\
- \\
- \\
-\end{array}$ & $\begin{array}{l}- \\
- \\
- \\
-\end{array}$ & $\begin{array}{l}\text { Cardias } \\
\text { Cardias } \\
\text { Cardias } \\
\text { Cardias }\end{array}$ & $\begin{array}{l}\text { Malignant } \\
\text { stenosis }\end{array}$ & Nitinol uncovered & $\begin{array}{l}\text { Ave. } 5 \\
\text { months } \\
(1-11 \mathrm{~m})\end{array}$ & $\begin{array}{c}\text { X-ray }(14)+ \\
\text { endoscopy } \\
(12) \text {, without } \\
\text { specifying }\end{array}$ & Not described \\
\hline \multirow[t]{2}{*}{$\begin{array}{l}\text { Sugimoto (6) } \\
\text { ( } 2 \text { cases) }\end{array}$} & $\mathrm{F}$ & 56 & - & $\begin{array}{l}\text { Malignant } \\
\text { stenosis }\end{array}$ & $\begin{array}{l}\text { Gianturco-Z (2) } \\
\text { and Ultraflex (1) }\end{array}$ & 4 weeks & X-ray & $\begin{array}{l}\text { Digestive } \\
\text { bleeding }\end{array}$ \\
\hline & M & 62 & - & $\begin{array}{l}\text { Malignant } \\
\text { stenosis }\end{array}$ & $\begin{array}{l}\text { Ultraflex (2) and } \\
\text { Gianturco-Z (1) }\end{array}$ & 7 months & X-ray & $\begin{array}{c}\text { Peritoneal } \\
\text { carcinomatosis }\end{array}$ \\
\hline $\begin{array}{l}\text { Iguchi }(7) \\
\text { (1 case) }\end{array}$ & $\mathrm{F}$ & 42 & $\begin{array}{l}\text { Corporeal- } \\
\text { fundus }\end{array}$ & $\begin{array}{l}\text { Malignant } \\
\text { stenosis }\end{array}$ & Gianturco-Z & 80 days & X-ray & $\begin{array}{l}\text { Metastasis + } \\
\text { renal failure }\end{array}$ \\
\hline $\begin{array}{l}\text { Iwasaki (8) } \\
\text { (1 case) }\end{array}$ & M & 60 & - & $\begin{array}{l}\text { Malignant } \\
\text { stenosis }\end{array}$ & Gianturco-Z & 4 months & X-ray & Cachexia \\
\hline $\begin{array}{l}\text { Siersema }(9) \\
\text { (6 cases) }\end{array}$ & $\begin{array}{l}- \\
- \\
- \\
- \\
- \\
-\end{array}$ & $\begin{array}{l}- \\
- \\
- \\
- \\
- \\
-\end{array}$ & $\begin{array}{l}\text { Not described } \\
\text { Not described } \\
\text { Not described } \\
\text { Not described } \\
\text { Not described } \\
\text { Not described }\end{array}$ & $\begin{array}{c}\text { Malignant } \\
\text { stenosis } \\
\text { (one with fistula) }\end{array}$ & $\begin{array}{l}\text { Ultraflex covered } \\
\text { and Gianturco-Z }\end{array}$ & $\begin{array}{l}64 \text { days on } \\
\text { average }\end{array}$ & Endoscopy & $\begin{array}{l}\text { Progression of the } \\
\text { tumour in general }\end{array}$ \\
\hline \multirow{3}{*}{$\begin{array}{l}\text { Mancha-Centro } \\
\text { ( } 3 \text { cases, described } \\
\text { in this article) }\end{array}$} & $\mathrm{F}$ & 41 & Antrum & $\begin{array}{l}\text { Malignant } \\
\text { stenosis }\end{array}$ & Ultraflex (2) & 14 months & Endoscopy & Tumoral invasion \\
\hline & $\mathrm{F}$ & 58 & $\begin{array}{l}\text { Fundus- } \\
\text { corporeal }\end{array}$ & $\begin{array}{l}\text { Malignant } \\
\text { stenosis }\end{array}$ & Ultraflex (1) & 8 months & Endoscopy & $\begin{array}{c}\text { Peritoneal } \\
\text { carcinomatosis }\end{array}$ \\
\hline & M & 69 & Corporeal & $\begin{array}{l}\text { Malignant } \\
\text { stenosis }\end{array}$ & Ultraflex (1) & 4 months & Endoscopy & Tumoral invasion \\
\hline
\end{tabular}

M: male, F: female.

cluding tumor relapse, which are not amenable to surgery. Also these complications are associated with significant clinical signs such as dysphagia or weight loss. These problems are difficult to solve, particularly in patients who needed total gastrectomy, and who have an esophagoenteral anastomosis. Potential therapies include surgical bypass and various palliative treatments. There is little experience in the literature on the placement of expandable stents as a palliative treatment for tumor relapses at the esophagoenteral anastomosis after total gastrectomy (1-9).

There are 21 cases described in the literature, most of them by radiologists, without endoscopic control (1,2,5-8). Different types of metal stents have been used: Esophacoil ${ }^{\circledR}$, Wallstent $^{\circledR}$, Ultraflex ${ }^{\circledR}$, and Gianturco-Rosch Z stent ${ }^{\circledR}$, all ob- taining a similar effectiveness. The most frequent indication has been malignant stenoses from tumor relapse (15 cases) (3,5-9), followed by anastomosis leaks (4 cases), with the rest being for benign stenoses (2 patients) $(2,4)$. Table I shows the main characteristics of all cases described in the literature, including the cases discussed in this work.

In our series, the placing of expandable metal stents at the malignant stenosis in patients with total gastrectomy has brought about a clear and obvious symptomatic improvement. This palliative treatment has allowed ingestion and improvement or disappearance of dysphagia. It has also helped in controlling weight loss, and even showed a weight gain for the first 2 patients. The placing of an Ultraflex ${ }^{\circledR}$-type stent under endoscopic control at the esophagoenteral anastomosis enables correct place- 
ment, and even removal when needed. Patient tolerability was optimal, with no difficulties in swallowing, except for tumor growth inside the stent. Experience as reported in the literature is consistent with our own, both in expandable stent effectiveness for palliative treatment, and lack of complications during their placement. In fact, the most frequent cause of death described in the literature has been tumor progression $(2,4-9)$ and secondary complications arising from neoplastic disease $(1,3)$. The cause of death in our patients was neoplastic invasion and progression. It does not seem that the type of stent used for the palliation of symptoms had any influence, although those most commonly used are Ultraflex ${ }^{\circledast}$ and Gianturco- $Z^{\otimes}$.

In summary, the placing of an esophagoenteral stent in the palliative treatment of dysphagia for tumor relapse in patients with total gastrectomy seemed effective. It allows oral ingestion, improves quality of life, and inhibits weight loss, and it can also help in the implementation of palliative chemotherapy as well.

\section{REFERENCES}

1. Roy-Choudhury SH, Nicholson AA, Wedgwood KR, Mannion RA, Sedman PC, Royston CM, et al. Symptomatic malignant gastresophageal anastomotic leak: management with covered metallic esophageal stents. Am J Roentgenol 2001; 176: 161-5.
2. Ustundag Y, Koseoglu T, Cetin F, Eroglu A, Soran A. Self-expandable metallic stent therapy of esophagojejunal stricture in a stapled anastomosis: a case and review of the literature. Dig Surg 2001; 18: 211-3.

3. Sherwood P, Duggan A, Shek F, Clarke D, Freeman J. Esophagojejunal stenting for recurrent gastric carcinoma. Gastrointest Endosc 1998; 47: 192-4.

4. Kozarek RA, Brandabur JJ, Raltz SL. Expandable stents: unusual locations. Am J Gastroenterol 1997; 92: 812-5.

5. Winkelbauer FW, Schofl R, Niederle B, Wildling R, Thurnher S, Lammer J. Palliative treatment of obstructing esophageal cancer with nitinol stents: value, safety, and long-term results. Am J Roentgenol 1996; 166: 79-84.

6. Sugimoto K, Hirota S, Imanaka K, Kawabe T, Matsumoto S, Sugimura K. Application of self-expanding metallic stents to malignant stenosis following mechanically stapled esophagojejunostomy: report of two cases. Radiat Med 2000; 18: 133-7.

7. Iguchi H, Kimura Y, Yanada J, Murasawa M. Treatment of a malignant stricture after esophagojejunostomy with self-expanding metallic stent. Cardiovasc Intervent Radiol 1993; 16: 102-4.

8. Iwasaki T, Hayashi N, Kimoto T, et al. Application of a self-expanding metallic stent to a strictured esophagojejunostomy. Cardiovasc Intervent Radiol 1993; 16: 98-101.

9. Siersema PD, Scgrauwen SL, Van Blankenstein M, Steyerberg EW, Van der Gaast A, Tilanus HW, Dees J; Rotterdam Esophageal Tumor Study Group. Self-expanding metal stents for complicated and recurrent esophagogastric cancer. Gastrointestinal Endosc 2001; 54: 57986.

10. Zaragozano Guillén R, Galbe Sada R, Cobos Hernández MV, Simón MA, Antón A. Nuestra experiencia con las prótesis metálicas autoexpandibles tipo Wallstent en esófago (74 prótesis en 65 pacientes). Rev Esp Enferm Dig 1999; 91: 736-41.

11. Fernández Lobato R, Tobio R, Pinto I, Maillo C, Álvarez Sánchez J, Carabias A, et al. Prótesis autoexpandibles para paliación de gastroyeyunostomía no funcionante. Rev Esp Enferm Dig 1995; 87: 71-3. 